\title{
ANALISIS TINGKAT LITERASI KEUANGAN DAN PENGELOLAAN KEUANGAN UMKM PADA UMKM DI KOTA MATARAM
}

\author{
Aulia Latifatul Afifah \\ auliaafifah2211@gmail.com \\ Jurusan Akuntansi Fakultas Ekonomi dan Bisnis Universitas Mataram \\ Baiq Anggun Hilendri Lestari \\ hilendria@gmail.com \\ Jurusan Akuntansi Fakultas Ekonomi dan Bisnis Universitas Mataram \\ Lalu Takdir Jumaidi \\ takdirjumaidi@unram.ac.id \\ Jurusan Akuntansi Fakultas Ekonomi dan Bisnis Universitas Mataram
}

\begin{abstract}
ABSTRAK
Tujuan dari penelitian ini adalah untuk mengetahui tingkat literasi keuangan dan pengelolaan keuangan yang diterapkan UMKM di Kota Mataram. Penelitian ini merupakan penelitian deskriptif kuantitatif. Penelitian deskriptif adalah penelitian yang dilakukan untuk mengetahui keberadaan variabel mandiri, baik hanya pada satu variabel atau lebih tanpa membuat perbandingan atau menghubungkan dengan variabel lain. Dalam hal ini data kuantitatif berupa jawaban kuisioner pemilik UMKM mengenai literasi keuangan dan pengelolaan keuangan. Populasi dalam penelitian ini adalah UMKM di Kota Mataram yang telah terdaftar pada Dinas Perindustrian Koperasi dan UMKM Kota Mataram. Sampel yang digunakan dalam penelitian ini berjumlah 100 sampel yang diperoleh menggunakan rumus Slovin. Teknik pengambilan sampel pada penelitian ini menggunakan probability sampling menggunakan metode simple random sampling

Sumber data yang digunakan dalam penelitian ini adalah data primer. Dalam penelitian ini data primer yang diperoleh secara langsung dari sumbernya berupa hasil pengisian kuisioner responden (pemilik UMKM). Berdasarkan hasil analisis dan pembahasan, maka dapat disimpulkan bahwa dari 100 UMKM di Kota Mataram, memiliki tingkat literasi keuangan yang dilihat dari 4 indikator literasi keuangan yaitu indikator Pengetahuan Keuangan Pribadi Secara Umum (78\%), Simpanan \& Kredit (77\%), Investasi (74\%) dan Asuransi (75\%), sedangkan pengelolaan keuangan yang sudah diterapkan dapat dilihat dari 4 indikator pengelolaan keuangan yaitu indikator Penggunaan Anggaran (81\%), Pencatatan (67\%), Pelaporan (50\%), Pengendalian $(70 \%)$.
\end{abstract}

Kata Kunci : $\quad$ Pengetahuan Keuangan Pribadi Secara Umum, Simpanan \& Kredit, Investasi, Asuransi, Penggunaan Anggaran, Pencatatan, Pelaporan, dan Pengendalian.

\section{ABSTRACT}

The purpose of this study was to determine the level of financial literacy and financial management applied by MSMEs in the city of Mataram. This research is quantitative descriptive. Descriptive research is research conducted to determine the existence of independent variables, either only on one or more variables without making comparisons or linking them with other variables. In this case, the quantitative data is in the form of answers to the MSME owner questionnaire regarding financial literacy and financial management. The population in this study were MSMEs in Mataram City which had been registerd by the Coorperative Industry Service and MSME. The sample used in this study amounted to 100 samples obtained using the Slovin formula. The sampling technique in this study used probability sampling using the method simple random sampling

The data source used in this study was primary data. In this study, primary data were obtained directly from the source in the form of the results of filling out questionnaires of respondents (MSME owners). Based on the results of the analysis and discussion, it can be concluded that out of 100 MSMEs in the City of Mataram, they have a level of financial literacy as seen from 4 indicators of financial literacy, namely the indicator of Personal Financial Knowledge in General (78\%), Savings \& Credit (77\%), Investment (74\%) and Insurance (75\%), while financial management that has been implemented can be seen from 4 
indicators of financial management, namely indicators of Budget Use (81\%), Recording (67\%), Reporting (50\%), Control (70\%).

Keywords: $\quad$ Personal Financial Knowledge in General, Savings \& Credit, Investment, Insurance, Budget Use, Recording, Reporting, and Control

\section{PENDAHULUAN}

Pertumbuhan ekonomi Indonesia setiap tahun mengalami peningkatan. Hasil ini mengindikasikan bahwa tingkat kesejahteraan masyarakat semakin membaik. Namun peningkatan kesejahteraan ini tidak diimbangi dengan pengetahuan masyarakat akan produk-produk jasa keuangan dan tidak diimbangi dengan kemampuan atau skill dalam mengelola keuangan. Pemahaman akan literasi keuangan semakin diperlukan demi terciptanya penduduk yang berkualitas dan memiliki kecerdasan finansial yang baik. Kebutuhan individu dan produk finansial yang semakin kompleks menuntut masyarakat untuk memiliki literasi keuangan yang memadai. Hal ini agar pengambilan keputusan mengenai pengelolaan keuangan tidak salah. Kekurangan literasi keuangan diakui sebagai salah satu faktor yang berkontribusi terhadap keputusan keuangan yang minim informasi sehingga menimbulkan dampak negatif, hal ini dikemukakan oleh Organitation for Economic Co-operation and Development/International Network on Financial Education (OECD/INFE 2009).

Bagi para pelaku Usaha Mikro, Kecil, dan Menengah (UMKM), pemahaman terhadap literasi keuangan sangat diperlukan. UMKM hingga saat ini menjadi perhatian pemerintah dalam hal kemampuannya untuk memperoleh akses dari lembaga keuangan yang terbuka seluasnya-luasnya dengan meniadakan hambatan terhadap akses memperoleh jasa lembaga keuangan terutama dalam proses pembiayaan yaitu dengan memperoleh kredit untuk membantu pelaku UMKM mengembangkan usahanya. UMKM memiliki peran penting dan mampu memberikan kontribusi bagi perekonomian Indonesia. Potensi UMKM yang besar merupakan suatu peluang untuk mengembangkan pasar dan industri Indonesia terutama dari sektor riil. Dengan memiliki literasi keuangan yang baik, akan sangat membantu UMKM dalam berbagai hal seperti dapat membuat Laporan Keuangan yang baik dimana ini akan memudahkan UMKM untuk mendapatkan pinjaman/suntikan dana yang membantu UMKM untuk menjalankan usahanya, penilaian kinerja perusahaan dan system pengendalian manajemen dianggap baik. Sebaliknya apabila UMKM memiliki literasi keuangan yang tidak baik akan sangat merugikan UMKM itu sendiri, seperti tidak dapat meyusun laporan keuangan dengan baik yang nantinya akan sangat sulit untuk mendapatkan pinjaman/suntikan dana, kualitas UMKM dianggap buruk, dan sulit dalam mengelola keuangan perusahaan sehingga akan berpengaruh buruk pada perkembangan perusahaan. Pengelolaan keuangan sangat penting bagi pelaku usaha mikro kecil menengah agar usaha yang dimiliki dapat berjalan dengan baik, jika sebuah usaha tidak memiliki pengelolaan keuangan yang baik hal ini akan membuat pemilik usaha bingung dalam pengambilan keputusan hal inilah yang nantinya dapat menghambat kemajuan dari usahanya.

Tujuan penelitian ini adalah untuk mengetahui bagaimana tingkat literasi keuangan yang dimiliki dan pengelolaan keuangan yang diterapkan UMKM di Kota Mataram.

\section{TINJAUAN LITERATUR}

Menurut Peraturan Otoritas Jasa Keuangan No 76/POJK.07/2016 Tentang Peningkatan Literasi dan Inklusi Keuangan di Sektor Jasa Keuangan Untuk Konsumen dan/atau Masyarakat bahwa literasi keuangan adalah pengetahuan, keyakinan, dan 


\section{Risinar}

Vol. 1 No. 4 Desember 2021

keterampilan yang mempengaruhi sikap dan perilaku untuk meningkatkan kualitas pengambilan keputusan dan pengelolaan keuangan dalam rangka mencapai kesejahteraan. Tujuan dari adanya literasi keuangan yaitu untuk meniadakan segala bentuk hambatan yang bersifat harga maupun non-harga, terhadap akses masyarakat dalam memanfaatkan layanan jasa keuangan. OJK juga membentuk program yaitu Strategi Nasional Literasi Keuangan Indonesia (SNLKI), program ini dibentuk sebagai upaya peningkatan literasi keuangan melalui pendidikan keuangan sejak dini hingga dewasa.

Menurut Chen dan Volpe (1998) dalam Pahrudin, dkk (2018) menyatakan bahwa kategori tingkat literasi individu dibedakan menjadi 3 bagian, yaitu: 1) Tingkat Literasi Rendah, jika nilai tingkat literasinya kurang dari 60\%;

2) Tingkat Literasi Sedang, jika nilai tingkat literasinya 60\%-80\%; dan 3) Tingkat Literasi Tinggi, jika memiliki tingkat literasi lebih dari 80\%.

Sedangkan Otoritas Jasa Keuangan membagi tingkat literasi keuangan penduduk Indonesia menjadi empat bagian, yakni:

1. Well Literate, yakni memiliki pengetahuan dan keyakinan tentang lembaga jasa keuangan serta produk dan jasa keuangan, termasuk fitur, manfaat dan risiko, hak dan kewajiban terkait produk dan jasa keuangan, serta memiliki keterampilan dalam menggunakan produk dan jasa keuangan.

2. Sufficient literate, memiliki pengetahuan dan keyakinan tentang lembaga jasa keuangan serta produk dan jasa keuangan, termasuk fitur, manfaat dan risiko, hak dan kewajiban terkait produk dan jasa keuangan

3. Less literate, hanya memiliki pengetahuan tentang lembaga jasa keuangan, produk dan jasa keuangan

4. Not literate, tidak memiliki pengetahuan dan keyakinan terhadap lembaga jasa keuangan serta produk dan jasa keuangan, serta tidak memiliki keterampilan dalam menggunakan produk dan jasa keuangan.

Merujuk pada penelitian Yushita (2017), financial literacy mencakup beberapa dimensi keuangan yang harus dikuasai. Chen dan Volpe (1998) menyebutkan beberapa dimensi financial literacy yang meliputi pengetahuan umum keuangan, tabungan dan pinjaman, asuransi, serta investasi.

Pengetahuan Umum Tentang Keuangan

Menurut S.P Wagland dan S. Taylor (2009), pengetahuan tentang keuangan mencakup pengetahuan keuangan pribadi, yakni bagaimana mengatur pendapatan dan pengeluaran, serta memahami konsep dasar keuangan. Konsep dasar keuangan tersebut mencakup perhitungan tingkat bunga sederhana, bunga majemuk, pengaruh inflasi, opportunity cost, nilai waktu uang, likuiditas suatu aset, dan lain-lain

Tabungan dan Pinjaman

Menurut Garman dan Forgue (2010:376), tabungan adalah akumulasi dana berlebih yang diperoleh dengan sengaja mengkonsumsi lebih sedikit dari pendapatan.

Dalam pemilihan tabungan, ada enam faktor yang perlu dipertimbangkan (Kapoor, et al., 2004:147), yaitu:

1) Tingkat pengembalian (persentase kenaikan tabungan)

2) Inflasi (perlu dipertimbangkan dengan tingkat pengembalian karena dapat mengurangi daya beli)

3) Pertimbangan pajak

4) Likuiditas (kemudahan dalam menarik dana jangka pendek tanpa kerugian atau dibebanifee) 
5) Keamanan (ada tidaknya proteksi terhadap kehilangan uang jika bank mengalami kesulitan keuangan)

6) Pembatasan-pembatasan dan fee (penundaan atas pembayaran bunga yang dimasukkan dalam rekening dan pembebanan fee suatu transaksi tertentu untuk penarikan deposito).

7) Asuransi

Menurut risiko keuangan, dengan cara pengumpulan unit-unit eksposur (exposure) dalam jumlah yang memadai, untuk membuat agar kerugian individu dapat diperkirakan. Kemudian, kerugian yang dapat diramalkan itu dipikul merata oleh mereka yang tergabung.

Investasi

Menurut Garman dan Forgue (2010:376), investasi adalah menyimpan atau menempatkan uang agar bisa bekerja sehingga dapat menghasilkan uang yang lebih banyak. Cara yang sering digunakan seseorang dalam berinvestasi yakni dengan meletakkan uang ke dalam surat berharga termasuk saham, obligasi dan reksa dana, atau dengan membeli real estate.

Pengelolaan Keuangan

Menurut James C. Van Horne dalam Kasmir (2010:5) dalam Rumbianingrum dkk (2018) mendefinisikan manajemen keuangan atau pengelolaan keuangan adalah segala aktivitas yang berhubungan dengan perolehan, pendanaan, dan pengelolaan aktiva dengan beberapa tujuan menyeluruh. Sedangkan menurut Irawati dalam Mulyawan (2015:30) dalam Rumbianingrum dkk (2018) mengatakan bahwa manajemen keuangan adalah proses pengaturan aktivitas atau kegiatan keuangan dalam suatu organisasi yang didalamnya termasuk kegiatan planning, analisis, dan pengendalian terhadap keuangan.

Pada pengelolaan keuangan UMKM atau perusahaan terdapat beberapa proses pengelolaan keuangan yang harusnya dilakukan. Terdapat empat kerangka dasar pengelolaan, yaitu:

\section{Perencanaan/Penggunaan Anggaran}

Perencanaan merupakan kegiatan menetapkan tujuan organisasi dan memilih cara yang terbaik untuk mencapai tujuan tersebut. Menurut Kuswadi (2005) dalam Diyana (2017) kegiatan perencanaan pada keuangan, salah satunya adalah merumuskan sasaran keuangan tahunan dan jangka panjang, serta anggaran keuangan. Penyusunan anggaran merupakan proses untuk membantu melaksanakan fungsi perencanaan dan pengendalian yang efektif. Anggaran merupakan suatu rencana yang dibuat oleh perusahaan dan dinyatakan dalam bentuk moneter. Menurut Adisaputro (2011) dalam Diyana (2017), anggaran sebagai alat pencapai tujuan perusahaan, yaitu dalam rangka memperoleh laba. Jenis-jenis anggaran penganggaran komprehensif adalah:

1) Anggaran Produksi

2) Anggaran Penjualan

3) Anggaran Modal

4) Anggaran Laba b. Pencatatan

Pencatatan merupakan kegiatan mencatat transaksi keuangan yang telah terjadi, penulisannya secara kronologis dan sistematis. Pencatatan sendiri digunakan sebagai penanda bahwa telah terjadi transaksi yang terjadi pada periode yang ditentukan dalam organisasi. Penyusunan pencatatan diawali dari pengumpulan dokumen yang mendukung terjadinya transaksi. Contohnya nota, kuitansi, faktur, dll. Langkah selanjutnya menulis transaksi dalam jurnal, lalu di posting ke dalam buku besar. Jenis-jenis catatan adalah jurnal, buku besar, worksheet. c. Pelaporan 


\section{Risinar}

Vol. 1 No. 4 Desember 2021

Pelaporan merupakan langkah selanjutnya setelah selesai memosting ke buku besar, dan buku besar pembantu. Postingan dalam buku besar dan buku besar pembantu akan ditutup pada akhir bulan, setelah itu akan dipindahkan ke ikhtisar laporan keuangan sebagai dasar penyusunan laporan keuangan. Jenis-jenis laporan keuangan ada Laporan Arus Kas, Laporan Laba Rugi, Laporan Posisi Keuangan

\section{Pengendalian}

Pengendalian merupakan proses mengukur dan mengevaluasi kinerja aktual dari setiap bagian organisasi, apabila diperlukan akan dilakukan perbaikan. Pengendalian dilakukan untuk menjamin bahwa perusahaan atau organisasi mampu mencapai tujuan yang telah ditetapkan. Jenis-jenis pengendalian adalah pengendalian awal, pengendalian berjalan, dan pengendalian umpan balik

Menurut Wibowo (2002) dalam Siregar, I.R (2018) kunci utama dalam mengelola keuangan adalah pembukuan dan administrasi yang rapih dan tepat. Menurut pengalaman, pengendalian keuangan yang lemah dan administrasi yang kacau menjadi salah satu sebab utama gagalnya perusahaan. Setiap rupiah yang keluar dan masuk harus dicatat secermat mungkin.

\section{Usaha Mikro Kecil Dan Menengah (UMKM)}

Menurut Undang-Undang Nomor 20 tahun 2008 tentang Usaha Mikro, Kecil dan Menengah, UMKM didefenisikan sebagai berikut:

1. Usaha Mikro adalah usaha produktif milik orang perorangan dan/atau badan usaha perorangan yang memenuhi kriteria Usaha Mikro sebagaimana diatur dalam UndangUndang ini.

2. Usaha Kecil adalah usaha ekonomi produktif yang berdiri sendiri, yang dilakukan oleh orang perorangan atau badan usaha yang bukan merupakan anak perusahaan atau bukan cabang perusahaan yang dimiliki, dikuasai, atau menjadi bagian baik langsung maupun tidak langsung dari Usaha Menengah atau Usaha Besar yang memenuhi kriteria Usaha Kecil sebagaimana dimaksud dalam Undang-Undang ini.

3. Usaha Menengah adalah usaha ekonomi produktif yang berdiri sendiri, yang dilakukan oleh orang perorangan atau badan usaha yang bukan merupakan anak perusahaan atau cabang perusahaan yang dimiliki, dikuasai, atau menjadi bagian baik langsung maupun tidak langsung dengan Usaha Kecil Atau Usaha Besar dengan jumlah kekayaan bersih atau hasil penjualan tahunan sebagaimana dimaksud dalam Undang-Undang ini.

Berdasarkan kekayaan dan hasil penjualan, menurut Undang-Undang Nomor 20 tahun 2008 pasal 6, kriteria usaha mikro kecil dan menengah yaitu:

Usaha Mikro

Memiliki kekayaan bersih paling banyak Rp 50.000.000,00 (lima puluh juta rupiah) tidak termasuk tanah dan bangunan tempat usaha; atau memiliki hasil penjualan tahunan paling banyak Rp 300.000.000,00 (tiga ratus juta rupiah)

\section{Usaha Kecil}

Memiliki kekayaan bersih lebih dari Rp 50.000.000,00 (lima puluh juta rupuah) sampai dengan paling banyak Rp 500.000.000,00 (lima ratus juta rupiah) tidak termasuk tanah dan bangunan tempat usaha; atau

Memiliki hasil penjualan tahunan lebih dari Rp 300.000.000,00 (tiga ratus juta rupiah) sampai dengan paling banyak Rp 2.500.000.000,00 (dua milyar lima ratus juta rupiah). 


\section{Usaha Menengah}

a) Memiliki kekayaan bersih lebih dari Rp 500.000.000,00 (lima ratus juta rupiah) sampai dengan paling banyak Rp 10.000.000.000,00 (sepuluh milyar rupiah) tidak termasuk tanah dan bangunan tempat usaha; atau

b) Memiliki hasil penjualan tahunan lebih dari Rp 2.500.000.000,00 (dua milyar lima ratus juta rupiah) sampai dengan paling banyak Rp 50.000.000.00,00 (lima puluh milyar rupiah)

\section{METODE PENELITIAN}

Jenis penelitian ini adalah penelitian deskriptif kuantitatif. Jenis penelitian ini termasuk penelitian deskriptif yang dilaksanakan melalui pengumpulan data di lapangan dengan kuesioner sebagai alat pengumpulan data. Metode penelitian yang digunakan adalah metode survei. Penelitian survei merupakan suatu penelitian kuantitatif dengan menggunakan pertanyaan-pertanyaan terstruktur atau sistematis yang sama kepada banyak orang kemudian seluruh jawaban yang diperoleh akan dicatat, diolah dan dianalisis. Penelitian ini dilaksanakan secara terpusat di Kota Mataram. Populasi dalam penelitian ini mencakup UMKM di Kota Mataram yang telah tercatat oleh Dinas Perindustrian Koperasi dan UKM tahun 2018 yaitu sebanyak 38.041 unit. Sedangkan penarikan sampel menggunakan rumus slovin adalah sebanyak 100 pelaku UMKM

Teknik pengambilan sampel pada penelitian ini menggunakan probability sampling menggunakan metode simple random sampling. Menurut Sugiyono (2018) probability sampling merupakan teknik pengambilan sampel yang memberikan peluang/kesempatan yang sama bagi setiap unsur atau anggota populasi untuk dipilih menjadi sampel. Simple random sampling adalah teknik pengambilan sampel dari anggota populasi yang dilakukan secara acak tanpa memperhatikan strata yang ada dalam populasi itu. Jenis data yang digunakan dalam penelitian ini adalah data kuantitatif. Sedangkan sumber data dalam penelitian ini adalah data primer. Teknik pengumpulan data dalam penelitian ini melalui kuesioner yang dibagikan langsung dan melalui google form kepada responden. Variabel dalam penelitian ini adalah Tingkat Literasi Keuangan dan Pengelolaan Keuangan UMKM. Indikator literasi keuangan menurut Chen dan Volpe (1998) adalah pengetahuan umum tentang keuangan, tabungan dan pinjaman, asuransi dan investasi. Sedangkan indikator pengelolaan keuangan menurut Kuswadi (2005) adalah indikator perencanaan, pencatatan, pelaporan, dan pengendalian. IndikatorIndikator tersebut diukur dengan menggunakan skala likert 


\begin{tabular}{|c|c|c|c|c|}
\hline \multicolumn{5}{|c|}{ LITERASI KEUANGAN } \\
\hline \multirow[t]{2}{*}{ Indikator } & $\begin{array}{l}\text { Tingkat } \\
\text { Literasi Tinggi } \\
\qquad(>80 \%)\end{array}$ & $\begin{array}{l}\text { Tingkat } \\
\text { Literasi } \\
\text { Sedang } \\
(60 \%-80 \%)\end{array}$ & $\begin{array}{l}\text { Tingkat } \\
\text { Literasi } \\
\text { Rendah } \\
(<60 \%)\end{array}$ & \\
\hline & (unit) & (unit) & (unit) & \\
\hline \multicolumn{5}{|c|}{$\overline{\text { Pengelolaan Keuangan Pribadi }}$} \\
\hline Secara Umum & 30 & 67 & 3 & \\
\hline $\begin{array}{l}\text { Simpanan \& Kredit } \\
\text { Investasi }\end{array}$ & 16 & $\begin{array}{l}77 \\
88\end{array}$ & 7 & \\
\hline Asuransi & 12 & 84 & 4 & \\
\hline \multicolumn{5}{|c|}{ PENGELOLAAN KEUANGAN } \\
\hline \multirow[t]{2}{*}{ Indikator } & $\begin{array}{l}\text { Sangat Baik } \\
>75 \% 100 \%)\end{array}$ & $\begin{array}{l}\text { Cukup Baik } \\
(>50 \%-75 \%)\end{array}$ & $\begin{array}{l}\text { Kurang Baik } \\
(>25 \%-50 \%)\end{array}$ & $\begin{array}{l}\text { Tidak Baik } \\
(>0 \%-25 \%)\end{array}$ \\
\hline & (unit) & (unit) & (unit) & (unit) \\
\hline Penggunaan Anggaran & 70 & 28 & 2 & 0 \\
\hline Pencatatan & 22 & 71 & 6 & 1 \\
\hline Pelaporan & 8 & 42 & 39 & 11 \\
\hline Pengendalian & 13 & 83 & 1 & 3 \\
\hline
\end{tabular}

\section{Tingkat Literasi Keuangan UMKM}

\section{Pengetahuan Keuangan Pribadi Secara Umum}

Berdasarkan tabel di atas, UMKM yang memperoleh persentase $>80 \%$ sebanyak 30 UMKM, yang berarti dari 100 UMKM hanya 30 UMKM yang memiliki tingkat literasi tinggi dalam indikator pengetahuan keuangan pribadi secara umum. Sedangkan UMKM yang memperoleh persentase antara 60-80\% sebanyak 67 UMKM yang berarti dari 100 UMKM terdapat 67 UMKM yang memiliki tingkat literasi sedang dalam indikator pengetahuan keuangan pribadi secara umum, sedangkan UMKM yang memperoleh persentase $<60 \%$ sebanyak 3 UMKM yang berarti UMKM tersebut memiliki tingkat literasi rendah dalam indikator pengetahuan keuangan pribadi secara umum

\section{Simpanan dan Kredit}

Berdasarkan tabel di atas, UMKM yang memperoleh persentase $>80 \%$ sebanyak 16 UMKM yang berarti dari 100 UMKM hanya 16 UMKM yang sudah memiliki tingkat literasi tinggi dalam indikator simpanan dan kredit. UMKM yang memperoleh persentase antara 60-80\% sebanyak 77 UMKM yang berarti dari 100 UMKM hanya 77 UMKM yang memiliki tingkat literasi sedang dalam indikator simpanan dan kredit. Sedangkan UMKM yang memperoleh persentase $<60 \%$ sebanyak 7 UMKM yang berarti dari 100 UMKM hanya 7 UMKM yang memiliki tingkat literasi rendah dalam indikator simpanan dan kredit 


\section{Investasi}

Berdasarkan tabel di atas, UMKM yang memperoleh persentase $>80 \%$ sebanyak 10 UMKM yang berarti dari 100 UMKM hanya 10 UMKM yang memiliki tingkat literasi tinggi dalam indikator investasi. UMKM yang memperoleh persentase antara $60-80 \%$ sebanyak 88 UMKM yang berarti dari 100 UMKM hanya 88 UMKM yang memiliki tingkat literasi sedang dalam indikator investasi. Sedangkan UMKM yang memperoleh persentase $<60 \%$ sebanyak 2 UMKM yang berarti dari 100 UMKM hanya 2 UMKM yang memiliki tingkat literasi rendah dalam indikator investasi

\section{Asuransi}

Berdasarkan tabel di atas, UMKM yang memperoleh persentase $>80 \%$ sebanyak 12 UMKM, yang berarti dari 100 UMKM hanya 12 UMKM yang memiliki tingkat literasi tinggi dalam indikator asuransi. UMKM yang memperoleh persentase antara $60-80 \%$ sebanyak 84 UMKM yang berarti dari 100 UMKM hanya 84 UMKM yang sudah memiliki tingkat literasi sedang dalam indikator asuransi. Sedangkan UMKM yang memperoleh persentase $<60 \%$ sebanyak 4 UMKM yang berarti dari 100 UMKM hanya 4 UMKM yang sudah memiliki tingkat literasi rendah dalam indikator asuransi.

\section{Pengelolaan Keuangan UMKM Penggunaan Anggaran}

Berdasarkan tabel di atas, UMKM yang memperoleh persentase antara $>75 \%$ 100\% sebanyak 70 UMKM yang berarti dari 100 UMKM terdapat 70 UMKM yang sudah menerapkan indikator penggunaan anggaran dengan sangat baik. UMKM yang memperoleh persentase antara $>50 \%-75 \%$ sebanyak 28 UMKM yang berarti dari 100 UMKM terdapat 28 UMKM yang telah menerapkan indikator penggunaan anggaran dengan cukup baik. UMKM yang memperoleh persentase $>25 \%-50 \%$ sebanyak 2 UMKM yang berarti dari 100 UMKM terdapat 2 UMKM yang telah menerapkan indikator penggunaan anggaran dengan kurang baik. Sedangkan tidak ada UMKM yang memperoleh persentase $>0 \%-25 \%$ yang berarti dari 100 UMKM tidak ada yang menerapkan indikator penggunaan anggaran dengan tidak baik.

\section{Pencatatan}

Berdasarkan tabel di atas, UMKM yang memperoleh persentase $>75 \%-100 \%$ sebanyak 22 UMKM yang berarti dari 100 UMKM hanya 22 UMKM yang telah menerapkan indikator Pencatatan dengan sangat baik. UMKM yang memperoleh persentase $<50 \%-75 \%$ diperoleh 71 UMKM yang berarti dari 100 UMKM hanya 71 UMKM yang telah menerapkan indikator Pencatatan dengan cukup baik. UMKM yang memperoleh persentase $<25 \%-50 \%$ diperoleh 6 UMKM yang berarti dari 100 UMKM hanya 6 UMKM yang telah menerapkan indikator Pencatatan dengan kurang baik. Sedangkan yang memperoleh persentase $<0 \%-25 \%$ diperoleh 1 UMKM yang berarti dari 100 UMKM hanya 1 UMKM yang telah menerapkan indikator Pencatatan dengan tidak baik.

\section{Pelaporan}

Berdasarkan tabel di atas, UMKM yang memperoleh persentase $<75 \%-100 \%$ sebanyak 8 UMKM yang berarti dari 100 UMKM hanya 8 UMKM yang telah menerapkan indikator Pelaporan dengan sangat baik. UMKM yang memperoleh persentase $<50 \%-75 \%$ sebanyak 42 UMKM yang berarti dari 100 UMKM hanya 42 UMKM yang telah menerapkan indikator Pelaporan dengan cukup baik. UMKM yang memperoleh persentase $<25 \%-50 \%$ sebanyak 39 UMKM yang berarti dari 100 UMKM hanya 39 UMKM yang telah menerapkan indikator Pelaporan dengan kurang baik. Sedangkan yang memperoleh persentase $<0 \%-25 \%$ sebanyak 11 UMKM yang berarti 


\section{Risinar}

Vol. 1 No. 4 Desember 2021

dari 100 UMKM hanya 11 UMKM yang telah menerapkan indikator Pelaporan dengan tidak baik.

\section{Pengendalian}

Berdasarkan tabel di atas, UMKM yang memperoleh persentase $<75 \%-100 \%$ sebanyak 13 UMKM yang berarti dari 100 UMKM hanya 13 UMKM yang telah menerapkan indikator Pengendalian dengan sangat baik. UMKM yang memperoleh persentase $<50 \%-75 \%$ sebanyak 83 UMKM yang berarti dari 100 UMKM hanya 83 UMKM yang telah menerapkan indikator Pengendalian dengan cukup baik. UMKM yang memperoleh persentase $<25 \%-50 \%$ sebanyak 1 UMKM yang berarti dari 100 UMKM hanya 1 UMKM yang telah menerapkan indikator Pengendalian dengan kurang baik. Sedangkan UMKM yang memperoleh persentase $<0 \%-25 \%$ sebanyak 3 UMKM yang berarti dari 100 UMKM hanya 3 UMKM yang telah menerapkan indikator Pengendalian dengan tidak baik.

Nilai Maksimum dan Minimum Literasi Keuangan dan Pengelolaan Keuangan Nilai Literasi Keuangan dan Pengelolaan Keuangan

\begin{tabular}{lll}
\hline \multicolumn{1}{c}{ Indikator } & Tertinggi & Terendah \\
\hline Literasi Keuangan & $99 \%$ (Bombai Textile) & $49 \%$ (Mataram Watch) \\
Pengelolaan Keuangan & $94 \%$ (UD Hendra) & $29 \%$ (Tobby dan UD Wahyu)
\end{tabular}

Berdasarkan tabel di atas, nilai rata-rata responden dari keempat indikator literasi keuangan, yang memiliki tingkat literasi paling tinggi adalah Bombai Textile (99\%) yang berarti dalam semua indikator pertanyaan tersebut Bombai Textile sudah menerapkan $99 \%$ atau $>80 \%$ sehingga dapat dikatakan UMKM Bombai Textile memiliki tingkat literasi tinggi sedangkan yang paling rendah adalah $49 \%$ diperoleh oleh Mataram Watch yang berarti dalam semua indikator pertanyaan tersebut Mataram Watch hanya menerapkan $49 \%$ atau $<60 \%$ sehingga dapat dikatakan UMKM Mataram Watch memiliki tingkat literasi rendah

Berdasarkan dari tabel di atas, yang menerapkan pengelolaan keuangan paling tinggi adalah UD Hendra (94\%) yang berarti dalam semua indikator pertanyaan tersebut UD Hendra sudah menerapkan $94 \%$ dari item pertanyaan, atau antara $75 \%-100 \%$, sehingga dapat dikatakan pengelolaan keungan yang diterapkan UMKM UD. Hendra sudah sangat baik, sedangkan yang paling rendah adalah 29\% diperoleh oleh 2 UMKM yang berarti UMKM Tobby dan UD Wahyu tersebut sudah menerapkan 29\% dari item pertanyaan, atau antara $25 \%-50 \%$, sehingga dapat dikatakan pengelolaan keuangan yang diterapkan 2 UMKM tersebut kurang baik

Kesimpulan Tingkat Literasi Keuangan
\begin{tabular}{|l|c|c|}
\hline \multicolumn{2}{|c|}{ LITERASI KEUANGAN } \\
\hline \multicolumn{1}{|c|}{ Indikator } & $\begin{array}{c}\text { Nilai Rata- } \\
\text { Rata }\end{array}$ & Keterangan \\
\hline $\begin{array}{l}\text { Pengetahuan Keuangan Pribadi Secara } \\
\text { Umum }\end{array}$ & $78 \%$ & Tingkat Literasi Sedang \\
\hline Simpanan \& Kredit & $77 \%$ & Tingkat Literasi Sedang \\
\hline
\end{tabular}


Aulia Latifatul Afifah, dkk: Analisis Tingkat Literasi Keuangan Dan Pengelolaan Keuangan UMKM..........

\begin{tabular}{|l|c|c|}
\hline Investasi & $74 \%$ & Tingkat Literasi Sedang \\
\hline Asuransi & $75 \%$ & Tingkat Literasi Sedang \\
\hline Rata-rata & $\mathbf{7 6 \%}$ & Tingkat Literasi Sedang \\
\hline \multicolumn{2}{|c|}{ PENGELOLAAN KEUANGAN } \\
\hline Penggunaan Anggaran & $81 \%$ & Sangat Baik \\
\hline Pencatatan & $67 \%$ & Cukup Baik \\
\hline Pelaporan & $50 \%$ & Kurang Baik \\
\hline Pengendalian & $70 \%$ & Cukup Baik \\
\hline Rata-rata & $\mathbf{6 7 \%}$ & Cukup Baik \\
\hline
\end{tabular}

\section{KESIMPULAN}

Berdasarkan hasil analisis dan pembahasan, maka dapat disimpulkan bahwa dari 100 UMKM di Kota Mataram yang menjadi responden mengenai analisis tingkat literasi keuangan dan pengelolaan keuangan yang dilihat dari 4 indikator mengenai literasi keuangan yaitu indikator Pengetahuan Keuangan Pribadi Secara Umum (78\%) yang berarti UMKM memiliki tingkat literasi sedang karena memiliki persentase $\geq 60 \%-80 \%$, indikator Simpanan \& Kredit (77\%) yang berarti UMKM memiliki tingkat literasi sedang karena memiliki persentase $\geq 60 \%-80 \%$, indikator Investasi (74\%) yang berarti UMKM memiliki tingkat literasi sedang karena memiliki persentase $\geq 60 \%-80 \%$ dan indikator Asuransi (75\%) yang berarti UMKM memiliki tingkat literasi sedang karena memiliki persentase $\geq 60 \%-80 \%$. Jadi setelah menghitung rata-rata dari keempat indikator tersebut diperoleh persentase sebesar $76 \%$ yang berarti secara keseluruhan rata-rata tingkat literasi keuangan yang dimiliki UMKM di Kota Mataram sebesar $76 \%$ atau memiliki tingkat literasi sedang, karena memiliki persentase antara $\geq 60 \%-80 \%$.

Sedangkan indikator pengelolaan keuangan yaitu indikator Penggunaan Anggaran (81\%) yang berarti UMKM telah menerapkan indikator penggunaan anggaran antara $\geq 75 \%-100 \%$ yang berarti sangat baik. Indikator Pencatatan $(67 \%)$ yang berarti UMKM telah menerapkan indikator pencatatan antara $\geq 50 \%-75 \%$ yang berarti cukup baik. Indikator Pelaporan (50\%) yang berarti UMKM telah menerapkan indikator pelaporan antara $\geq 25 \%-50 \%$ yang berarti kurang baik, dan indikator Pengendalian (70\%) yang berarti UMKM telah menerapkan indikator pengendalian antara $\geq 50 \%-75 \%$ yang berarti cukup baik. Jadi setelah menghitung rata-rata dari keempat indikator tersebut diperoleh persentase sebesar $67 \%$ yang berarti secara keseluruhan rata-rata pengelolaan keuangan yang diterapkan UMKM di Kota Mataram sebesar $67 \%$ atau cukup baik, karena memiliki persentase antara $\geq 50 \%-75 \%$ 


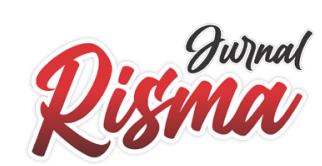

Vol. 1 No. 4 Desember 2021

\section{REFERENSI}

Al Falih, Muhammad Sabiq Hilal, Reza Muhammad Rizqi, Nova Aditya Ananda. 2019. Pengelolaan Keuangan dan Pengembangan Usaha Pada Usaha Mikro Kecil Menengah (Studi Kasus Pada UMKM Madu Hutan Lestari Sumbawa). Jurnal Manajemen dan Bisnis Vol.2 NO.12019.

Anggraeni, Birawani Dwi. 2015. Pengaruh Tingkat Literasi Keuangan Pemilik Usaha Terhadap Pengelolaan Keuangan. Studi Kasus: UMKM Depok. Jurnal Vokasi Indonesia Volume 3 Nomor 1.

Arikunto, Suharsimi. 2004. Prosedur Penelitian. Jakarta: Rineka Cipta.

Desriana, Neny, Pigo Nauli, Prayudha Ananta, Doni S. Warganegara. 2017. Pelatihan Literasi Keuangan Untuk Peserta Program Business Cart (Gerobak Dagang) PKPU Human Initiative Bekerja Sama Dengan Germany Muslimhelfen, Di Kecamatan Teluk Betung Timur, Bandar Lampung. Skripsi. Universitas Lampung.

Diyana Ita Yustian Free. 2017. Analisis Pengelolaan Keuangan Usaha Mikro Kecil dan Menengah. Studi Kasus Pada Asosiasi Batik Mukti Manunggal Kabupaten Sleman. Skripsi. Universitas Sanata Dharma Yogyakarta.

Ediraras Dharma T. 2010. Akuntansi dan Kinerja UKM. Jurnal Ekonomi Bisnis No. 2, Volume 15.

Harianti, Widya Septiana. Analisis Pengelolaan Keuangan Pada Usaha Mikro Kecil dan Menengah (UMKM) Di Kota Mataram. Skripsi. Universitas Mataram.

Ichwan, Cynthia Nur Fitriana. 2016. Studi Literasi Keuangan Pengelola Usaha Kecil Menengah Pada Wilayah Gerbangkertasusila. Undergraduate thesis, STIE Perbanas Surabaya.

Kuswadi. 2005. Meningkatkan Laba Melalui Pendekatan Akuntansi Keuangan dan Akuntansi Biaya. PT. Elex Media Komputindo, Jakarta.

Lestari, B. Anggun Hilendri, Sapto Hendri BS, L. Takdir Jumaidi, D. Tialurra Della Nabila. Akuntansi Perspektif Usaha Mikro Kecil Menengah (Survei Pada UMKM di Kota Mataram). 2020. JMM, Vol. 4, No. 2, April 2020.

Margaretha, Farah, Reza Arief Pambudhil. Tingkat Literasi Keuangan Pada Mahasiswa S1 Fakultas Ekonomi. 2015. JMK, VOL. 17, NO. 1, MARET 2015, 76-85.

Octaviani, Made Sita Diaz, Putu Eka Dianita Marvilianti Dewi, Putu Sukma Kurniawan. 2018. Analisis Pengelolaan Keuangan UMKM Dalam Upaya Pembinaan Kemandirian Warga Binaan Pemasyarakatan (WBP) Rumah Tahanan Kelas II B Negara (Studi Kasus Pada Rumah Tahanan Kelas IIB Negara). JIMAT (Jurnal Ilmiah Mahasiswa Akuntansi) Universitas Pendidikan Ganesha, Vol: 9 No: 2 Tahun 2018.

Peraturan Otoritas Jasa Keuangan No 76/POJK.07/2016 Tentang Peningkatan Literasi dan Inklusi Keuangan di Sektor Jasa Keuangan Untuk Konsumen dan/atau Masyarakat.

Purwanti, Endang. 2013. Analisis Pengetahuan Laporan Keuangan Pada UMKM Industri Konveksi di Salatiga. Jurnal Ilmiah Among Makarti Vol 11 Nomor 20.

Putra, M Rizky J. 2020. Analisis Tingkat Literasi Keuangan Pelaku UMKM Perempuan di Pasar Nangkaan Kabupaten Bondowoso. Skripsi. Universitas Muhammadiyah Jember.

Ramadhan, Dadan. 2019. Analisis Tingkat Literasi Keuangan Pada Pelaku Usaha Mikro di Kabupaten Kulon Progo Daerah Istimewa Yogyakarta. Skripsi. Universitas Muhammadiyah Yogyakarta. 
Rumbianingrum, Wahyu, Candra Wijayangka. 2018. Pengaruh Literasi Keuangan Terhadap Pengelolaan Keuangan UMKM. Jurnal Manajemen dan Bisnis (ALMANA) Vol. 2 No. 3.

Siregar, Ihelsa Rumondang. 2018. Pengaruh Literasi Keuangan Terhadap Pengelolaan Keuangan UMKM di Kota Bogor. Skripsi. Institut Pertanian Bogor.

Susanti, Ari, Ismunawan, Pardi, Elia Ardyan. 2017. Tingkat Pendidikan, Literasi Keuangan, dan Perencanaan Keuangan Terhadap Perilaku Keuangan UMKM di Surakarta. Telaah Bisnis Volume 18, Nomor 1.

Undang-Undang Nomor 20 tahun 2008 tentang Usaha Mikro, Kecil dan Menengah.

Undang-undang Perbankan No. 10 tahun 1998.

Warsono. 2010. Prinsip-Prinsip dan Praktik Keuangan Pribadi. Volume 13 Nomor 2.

Yushita, Amanita Novi. 2017. Pentingnya Literasi Keuangan Bagi Pengelolaan Keuangan Bagi Pengelolaan Keuangan Pribadi, Jurnal Nominal/Volume V1 Nomor 1.

http://www.depkop.go.id. Diakses 2 Januari 2020 pukul 07.13 WITA http://iaiglobal.or.id/v03/files/draft_ed_sak_emkm_kompilasi.pdf. Diakses 10 Januari 2020 pukul 13.02 WITA

http://diskop.ntbprov.go.id. Diakses 10 Januari 2020 pukul 13.06 WITA http://diskop.ntbprov.go.id/jumlah-ukm-se-ntb-data-bps-tahun-2006-2017/.

Diakses pada 20 Januari 2020. Pukul 19.54 WITA http://diskop.ntbprov.go.id/datacenter/?p=197. Diakses pada 20 Januari 2020. Pukul 19.56 WITA

https://www.republika.co.id/berita/ekonomi/keuangan/19/01/16/plff77423-bi-dorongkemajuan-sektor-umkm-ntb. Diakses pada 20 Januari 2020. Pukul 19.58 WITA.

https://www.kajianpustaka.com/2018/03/pengertian-tingkat-aspek-dan-pengukuranliterasi-keuangan.html. Diakses 17 Februari 2020 Pukul 17.38 WITA.

https://www.seputarpengetahuan.co.id/2018/05/pengertian-literasi-keuangan-tingkataspek-indikator.html. Diakses 17 Februari 2020 Pukul 17.42 WITA.

https://www.beritasatu.com/ekonomi/515732/survei-oecd-umkm-ri-paling-banyakserap-tenaga-kerja. Diakses 17 Februari 2020 Pukul 17.46 WITA.

https://www.ojk.go.id/id/berita-dan-kegiatan/siaran-pers/Pages/Siaran-Pers-SurveiOJK-2019-Indeks-Literasi-Dan-Inklusi-Keuangan-Meningkat.aspx. Diakses 25 Februari 2020 pukul 09.56 WITA.

https://www.ojk.go.id/id/berita-dan-kegiatan/siaran-pers/Documents/Pages/Siaran-PersOJK-Indeks-Literasi-dan-Inklusi

KeuanganMeningkat/17.01.23\%20Tayangan\%20\%20Presscon\%20\%20nett.com pressed.pdf. Diakses 25 Februari 2020 pukul 09.58 WITA

https://www.ojk.go.id/id/berita-dan-kegiatan/publikasi/Documents/Pages/StrategiNasional-Literasi-Keuangan-Indonesia(Revisit-2017)-

/SNLKI\%20(Revisit\%202017).pdf Diakses 25 Februari 2020 pukul 10.02 WITA. https://sikapiuangmu.ojk.go.id/FrontEnd/images/Document/buku\%20statistik_2016.pdf. Diakses 25 Februari 2020 pukul 10.08 WITA 